\title{
Libel and College Coaches
}

\author{
PAMELA C. LAUCELla, \\ $\&$ \\ BARBARA OSBORNE, \\ University of North Carolina at Chapel Hill
}

\section{AN INTRODUCTION TO THE COACH AND SPORTS JOURNALIST RELATIONSHIP}

The relationship between college coaches and the journalists who continuously critique and interpret their actions remains an enigma. There is a co-dependent element to the relationship. The coach relies on the media to generate interest in the program, keep the program visible, and consequently help drive ticket sales and viewership of games. On the other hand, the journalist needs the coach to provide information and allow access to the team practices and games, as well as to the athletes. Although it would seem that professional conduct and courtesy on both sides would yield the greatest reward, there is the potential for an inherent clash between the coach's individual interest of reputation and the journalist's desires to feed the public's insatiable appetite for information.

Coach Steve Lavin, men's basketball coach at the University of California at Los Angeles (UCLA), admitted he is suspicious of the media. Professed Lavin, "[t]he reality of coaching remains that your program will be analyzed, scrutinized, and dissected like a frog in a biology class." ${ }^{1}$ He added, "Once you're burned by reporters, it's difficult to trust them again." 2 A year after Lavin endured 'Pitinogate,' the swirling rumors about his termination, and an email attack from Dave Gibson alleging potential NCAA violations; he closed practices to the press corps for the first time in UCLA's history. ${ }^{3}$

1. Telephone Interview with Steve Lavin, Men's Head Basketball Coach, University of California-Los Angeles (December 7, 2000).

2. Telephone Interview with Steve Lavin, Men's Head Basketball Coach, University of California-Los Angeles (October 12, 2000).

3. Phil Taylor, UCLA: A Secret the Deep, Talented Bruins Can't Keep: They're of Championship Caliber, SPORTS ILLUSTRATED, Nov. 19, 2001, at 104. "Pitinogate" refers to an incident during the 2000-01 basketball season where UCLA athletic director Pete Dalis lied to Lavin about calling Rick Pitino to discuss the possibility of replacing Lavin. 
Disparate perspectives exist towards sports journalists' treatment of coaches and the relationship between the two. On one hand, the sports media often cover the legal, political, ethical, and sociological implications of sport, positioning the story in context or transcending the singular post-game interview. This perspective triggers a negative view of the media's treatment of coaches since journalists act as watchdogs and critics. ${ }^{4}$ Joe Fitzgerald of the Boston Herald said, "[o]pinion today is more adversarial, more intrusive, more inclined to pander to the public's 'desire' to know under the guise of its 'right' to know. I see too many columnists measuring celebrities against litmus tests we ourselves could not pass."5 Will McDonough of the Boston Globe added, "[e]thics are nonexistent. It's okay to make something up as long as you don't get caught. It's sad."6

On the other hand, many dispute the perception of an overly critical journalist and instead believe sports journalists cajole and protect their sources. Steve Rushin of Sports Illustrated suggested a trend towards "nonjudgmentalism" in sports as evident in the media and society's treatment of two coaches with vitriolic tempers, University of Texas-El Paso basketball coach Bob Knight and ex-Chicago Bears and New Orleans Saints' NFL coach Mike Ditka. ${ }^{7}$ Said Rushin, "[t]he new Non-Judgmentalism may merely reflect a disingenuous desire among public figures to preempt criticism. When nobody judges, everything is condoned."8 Dr. James Carey of Columbia University agreed with Rushin, adding that meritorious college coaches enjoy "clout" with legislators and public officials due to the media. ${ }^{9}$ Indiana University did everything they could to retain Knight because according to Carey, "Bobby Knight is perhaps the most powerful public figure in Indiana and very few people... are willing to cross him."10 Said Carey, "These legends are made, made by sports writers ... Sports journalism generally is blind to politics and power and sports writers willfully ignore the implications

4. The Pew Research Center for the People \& the Press, Striking The Balance: AUdiENCE INTERESTS, BusINESS PRESSURES AND JOURNALISTS' VALUES, Section III: Views on Performance, at http://208.240.91.18/press99sec3.htm (March 30, 1999) (hereinafter "STRIKING THE BALANCE"). Some journalists and media executives believe that they sometimes propel controversies rather than just covering news when they divulge personal and ethical issues of public figures. at 72 .

5. J. Sean McCleneghan, Sports Columnists Sound Off, EDITOR \& PUBLISHER, March 19, 1994,

6. Id. at 72 .

7. Steve Rushin, Rush from Judgment, SPORTS ILLUSTRATED, Jan. 10, 2000, at 24.

8. Id. at 24 .

9. James Carey, At Their Feet, Or At Their Throat, COlumBIA JOURNALISM REV., July/Aug. 2000 , at 56.

10. Id. 
of their own work in promoting and sustaining the omnipotence of college coaches. Of their relationship to coaches it truly can be said, they are either at their feet or at their throat."11

Of the six out of ten adults who read a newspaper in the United States today, two thirds of those read the sports sections, revealing a desire for regular and in-depth coverage of local teams. ${ }^{12}$ The demand for stories is constant and the demand for the coach's attention is equally unrelenting, especially due to the overwhelming pressures to win. The American public's interest in every detail of others' lives has expanded the market for criticism of all public figures, including college coaches. ${ }^{13}$ As a result, there has been a tendency in libel law to grant the press greater protection under the First Amendment of the United States Constitution, which means they have the freedom "to print anything concerning an athlete's [or coach's] life, both on and off the field." 14

While such libel cases as Curtis Publishing Co. v. Butts (1967) ${ }^{15}$ and Warford v. Lexington Herald-Leader Co. $(1990)^{16}$ represent one extreme of this sometimes tenuous journalist/source relationship between sports journalists and college coaches, such journalistic inaccuracies as misquotes and quotes out-of-context, the use of off-the-record material, and a discussion of an individual's private life, ${ }^{17}$ propel coaches' caution in dealing with the media and its ability to shape agendas. These cases will be discussed in detail later in this article.

This article will investigate the relationship between coaches and sports reporters analyzing libel and its potential in the journalist/source relationship. It will define libel and how courts have treated it, targeting those individual cases dealing with college coaches from Division I, II, and III institutions and journalists from electronic, print, and new media. It will include historical analysis of such seminal cases as New York Times Co. v. Sullivan (1964) ${ }^{18}$ and Gertz v. Robert Welch, Inc. (1974), ${ }^{19}$ and pertinent sport cases like Curtis

11. Id. at 56.

12. Matthew Reed Baker, Full Court Press, BRILls CONTENT, Apr. 2000, at 100.

13. Andrew K. Craig, The Rise in Press Criticism of the Athlete and the Future of Libel Litigation Involving Athletes and the Press, 4 SETON HALL J. SPORTS L. 527, 528 (1994).

14. Id. at 528 .

15. 388 U.S. 130 (1967).

16. 789 S.W.2d 758 (Ky. Sup. Ct. 1990).

17. Rick Telander, The Written Word: Player-Press Relationships in American Sports, 1 SoC. SPORT J. 3, 4 (1984).

18. 376 U.S. 254 (1964).

19. 418 U.S. 323 (1974). 
Publishing Co. ${ }^{20}$ and Warford. ${ }^{21}$ This will afford an understanding of the history of libel in the United States; its key concepts of public official, allpurpose public figure, limited purpose public person, and private figure classifications; and the historical development, application, precedent and significance of these libel decisions on college coaches and the media. Recommendations for both reporters and coaches will supplement the study.

The paper specifically seeks to answer the following questions:

- What is the history of libel, specifically related to cases dealing with college coaches and the media?

- Since New York Times v. Sullivan, how have the United States Supreme Court and federal appeals courts applied libel in cases involving college coaches?

- And finally, how can college coaches protect themselves from libelous statements and what defenses can the media use to combat such claims?

\section{DEFINITIONS AND LEGAL PROOF REQUIREMENTS}

Defamatory communication is one that "tends to harm the reputation of another as to lower him in the estimation of the community or to deter third persons from associating or dealing with him."22 A defamatory statement "exposes the plaintiff to public hatred, shame, contempt, or ridicule." 23 Defamatory material injures one's reputation or character and includes expression from "news stories, press releases, advertising, broadcasts, in-house memos, Internet messages, and speeches." 24 While both libel and slander constitute defamation, this paper will deal only with the former, the publication of defamatory matter by writing.

Barron's Law Dictionary defines libel as a "tort consisting of a false and malicious publication printed for the purpose of defaming one who is living." 25 The three classes of libel include libel per se (those matters which are obviously defamatory); statements that could either be considered

20. Curtis Publ'g Co., 388 U.S. 130 (1967).

21. 789 S.W. 2 d 758.

22. RESTATEMENT (SECOND) OF TORTS $§ 559$ (1977).

23. GLENN WONG, ESSENTIALS OF AMATEUR SPORTS LAW $386\left(2^{\text {nd }}\right.$ ed. 1994).

24. Kent R. Middleton Et Al., The Law Of Public Communication 79 ( $5^{\text {th }}$ ed. 2000).

25. BARRON'S LAW DiCTIONARY 276 ( ${ }^{\text {rd }}$ ed. 1991). 
defamatory or not defamatory; and finally, those statements that are defamatory when combined with other facts, but not on their own. ${ }^{26}$

To show libel, plaintiffs bear the burden of proving the elements of defamation: identification, publication, falsity, fault and personal harm. ${ }^{27}$ Identification means that the language is "of and concerning them" - that one reading the statement would be able to identify the plaintiff. ${ }^{28}$ Publication does not necessarily mean a media publication, any communication to a third person is sufficient. The legal requirement for publication is three persons; (1) the person publishing the defamation, (2) the person who it concerns, and (3) a third party who receives the communication. ${ }^{29}$ Fault can be proven if the defendant knew that the statement was false, or that there was a high degree of awareness of probable falsity, and published the statement anyway. ${ }^{30}$ The degree of care for publication is different depending upon whether the plaintiff is a public official or a private citizen. Public officials and public figures must prove actual malice, and private citizens prove negligence or recklessness. ${ }^{31}$ Personal harm includes actual damages for loss of good name or humiliation and special damages for lost revenues or expenses. Plaintiffs can also sue for punitive damages, which punish the libeler. ${ }^{32}$

Defendants can defend against a libel action if they prove any of the following:

(1) Truth

(2) Protection for opinion

(3) Exaggeration and figurative terms

(4) Opinion based on fact

(5) Totality of the circumstances

(6) Absolute privileges for government officials, consent, broadcasts for political candidates

(7) Or qualified privileges for journalists. ${ }^{33}$

26. WONG, supra note 23 , at 386 .

27. MIDDLETON et al., supra note 24 , at 76,79 .

28. Id.

29. Id.

30. Id.

31. Id. at 98 .

32. Id. at 128 .

33. Id. at 133-146. Opinions often cannot be proven false and as the Supreme Court said in Gertz, "[t]here is no such thing as a false idea." (Gertz, 418 U.S. at 339). Exaggerated terms like 
Additionally, some courts have recognized neutral reportage, where the media receives protection in reporting in a "fair, neutral, and accurate fashion" about public officials and figures outside their official capacity. ${ }^{34}$ Courts have also recognized the wire service defense, retraction statutes, and anti-SLAPP (strategic lawsuits against public participation) statutes. ${ }^{35}$ While plaintiffs usually must prove all elements of defamation, defendants must only prove one of these defenses to combat a claim. ${ }^{36}$

\section{HISTORY OF LIBEL AND KEY RULINGS}

The number of libel cases against the media has skyrocketed since the $1980 \mathrm{~s}^{37}$ The public's right to a free flow of information often clashes with the individual's interest in reputation and privacy. ${ }^{38}$ Defamation is a "counterbalance in the protection of an individual's reputation versus the Constitutional protection of speech and the press." 39

Before 1964 and the landmark edict of New York Times $v$. Sullivan, the plaintiff in libel cases never proved actual injury, damage was assumed, and to overcome falsity, defendants merely needed to prove their article was totally true. ${ }^{40}$ In fact, libel was considered a strict liability tort, which meant that the plaintiff could win a suit even if the defendant took precautions to ensure truth in publication. If the defendant published information that was defamatory

rhetorical hyperbole often are considered too vague to consider facts. People who read opinion based on fact do not necessarily consider the statements facts. Regarding the totality of circumstances, courts investigate whether statements are confirmable and also analyze the social context in which the statement occurred (Id. at 139-140). Government officials in their "official capacity" warrant absolute privilege from libel suits. However, journalists receive only qualified privileges when accurately reporting on official activities of legislative, judicial, and executive events (Id. at 143-144).

34. JOHN D. ZELEZNY, COMMUNiCATIONS LAW: LiberTIES, RESTRAINTS, AND THE MODERN MEDIA 140 (3rd ed. 2001).

35. Id. at 141-144. The wire service defense applies to the media's republication of materials from a news service without changing content and without realizing the information was false. Retraction statutes are recognized in 30 states and apply when the media publish a retraction in a certain amount of time. And finally, anti-SLAPP statutes present a procedure, which defendants can use to have the lawsuit thrown out of court.

36. MIDDLETON et al., supra note 24 , at 79.

37. Seth Goodchild, Note, Media Counteractions: Restoring the Balance to Modern Libel Law, 75 GEO. L.J. 315, 315 (1986).

38. Erik Walker, Comment, Defamation Law: Public Figures-Who are They?, 45 BAYLOR L. REV. 955, 955 (1993).

39. Craig, supra note 13 , at 529.

40. Id. at 530 . 
and false, the plaintiff always won regardless of the level of care the publisher used. ${ }^{41}$

The case of New York Times $v$. Sullivan changed the libel landscape dramatically. ${ }^{42}$ Sullivan was an elected official in Montgomery, Alabama who brought suit in state court alleging that he had been libeled by an advertisement in the New York Times. ${ }^{43}$ The advertisement included statements about police action allegedly directed against students who participated in a civil rights demonstration and against a leader of the civil rights movement. ${ }^{44}$ Some of the statements were inaccurate and others were false. Although Sullivan was not named directly in the advertisement, he claimed the statements referred to him because his duties included supervision of the police department. ${ }^{45}$ The trial judge instructed the jury that such statements were "libelous per se," legal injury being implied without proof of actual damages, and that malice was presumed for the purpose of compensatory damages, so that such damages could be awarded against The New York Times if the statements were found to have been published by them and to have related to respondent. ${ }^{46}$

As to punitive damages, the judge instructed that mere negligence was not evidence of actual malice and would not justify an award of punitive damages, but he refused to instruct that actual intent to harm or recklessness had to be found before punitive damages could be awarded, or that a verdict for the respondent should differentiate. between compensatory and punitive damages. ${ }^{47}$ The jury found for the respondent and the State Supreme Court affirmed. $^{48}$ The U.S. Supreme Court reversed and remanded, holding that under the First and Fourteenth Amendments a State cannot award damages to a public official for defamatory falsehood relating to his official conduct unless he proves "actual malice"-that the statement was made with knowledge of its falsity or with reckless disregard of whether it was true or false. $^{49}$ The Supreme Court found the evidence was constitutionally insufficient to support the judgment for Sullivan, since it failed to support a

41. ZELEZNY, supra note 34, at 119.

42. New York Times Co., 376 U.S. 254.

43. Id. at 265-292.

44. Id.

45. Id.

46. Id.

47. New York Times Co., 376 U.S. at 265-292.

48. New York Times Co. v. Sullivan, 273 Ala. 656 (Ala. 1962).

49. Id. at 264 . 
finding that the statements were made with actual malice or that they related to him. ${ }^{50}$ In New York Times the majority reasoned that criticism and robust wide open debate of public officials were a necessary party of the American political process. ${ }^{51}$ The press thereby received more freedom to criticize public officials. While the Court failed to define the term public official, later courts have considered "anyone elected to public office as well as government employees responsible for policy making or for public funds, health, or safety" as part of this category. ${ }^{52}$ However, the term "public official" does not apply to everyone on the government's payroll, only those at the highest levels. ${ }^{53}$

There have only been two libel cases that involve college coaches and the media: Curtis Publishing Co. ${ }^{54}$ and Warford. ${ }^{55}$

Curtis Publishing Co. remains a highly quoted case in libel law. In this case, the Saturday Evening Post published Frank Graham Jr.'s story, "The Story of a College Football Fix," 56 alleging that Athletic Director Wally Butts of the University of Georgia and legendary University of Alabama football coach Paul "Bear" Bryant, conspired to fix a football game between the two teams in 1962. ${ }^{57}$ The publication's "sophisticated muckraking" was evident in the editors' note prefacing the story. ${ }^{58}$ It read, "[n]ot since the Chicago White Sox threw the 1919 World Series has there been a sports story as shocking as this one." 59

The article was based on an affidavit from an Atlanta insurance salesman, George Burnett, who overheard a telephone conversation between Butts and Bryant one week prior to the game. He allegedly heard Butts divulge Georgia's offensive and defensive plays to the legendary Alabama coach, using specific players and plays by names. ${ }^{60}$ Butts brought a libel action in federal court seeking compensatory and punitive damages for the Post article, challenging the truth of the article as well as claiming a serious departure by the magazine from good investigative standards of the accuracy of its

50. Id.

51. New York Times, Co., 376 U.S. at 270.

52. MIDDLETON et al., supra note 24 , at 107.

53. ZELEZNY, supra note 34 , at 130.

54. Curtis Publ'g Co., 388 U.S. 130.

55. Warford, 789 S.W.2d at 758.

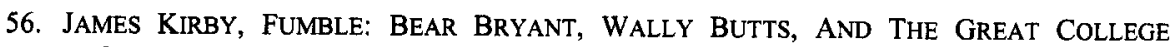
FOOTBALL SCANDAL 55 (1986).

57. Curtis Publ'g Co., 388 U.S. at 162-165.

58. KIRBY, supra note 56 , at 51 .

59. Id.

60. Curtis Publ'g Co., 388 U.S. at 136-137. 
charges. ${ }^{61}$ While evidence revealed that Burnett indeed heard a conversation between the two, its content remained unclear and fervently contested. The jury awarded Butts $\$ 60,000.00$ in general damages and $\$ 3,000,000.00$ in punitive damages, which was later reduced to $\$ 460,000.00$ by remittitur. ${ }^{62}$

The Saturday Evening Post failed on several accounts. First, they did not interview witness John Carmichael, a person who was with Burnett when the phone call was overheard. Although they assigned the story to a writer with no football expertise, the Post failed to have an expert check the article, did not view game films to verify information, nor check for changes in Alabama's game plans. ${ }^{63}$ After Butts and his daughter contacted the magazine to refute the story's contentions, the publication still refused to confirm the story's accuracy, even without deadline pressure. ${ }^{64}$ Thus according to the Court, "[t]he evidence is ample to support a finding of highly unreasonable conduct constituting an extreme departure from the standards of investigation and reporting ordinarily adhered to by responsible publishers." 65

The Justices reasoned,

The evidence showed that the Butts story was in no sense 'hot news' and the editors of the magazine recognized the need for a thorough investigation of the serious charges. Elementary precautions were, nevertheless, ignored. The Saturday Evening Post knew that Burnett had been placed on probation in connection with bad check charges, but proceeded to publish the story on the basis of his affidavit without substantial independent support. ${ }^{66}$

Although the Post lost this case, publishers gained additional constitutional protection as the court expanded the New York Times actual malice standard to defamation actions by 'public figures' as well as those by 'public officials. ${ }^{167}$ The Court considered Butts a public figure rather than a public official since the Georgia Athletic Association ${ }^{68}$ employed him rather than the university itself. ${ }^{69}$ Chief Justice Warren in his concurring remarks

61. Id. at 131 .

62. Id. at 138. Remittitur is the procedural process by which the verdict of a jury is reduced by the court without consent of the jury according to Black's Law Dictionary.

63. Id. at 157.

64. Id. at 161 .

65. Id. at 158 .

66. Curtis Publ'g Co., 388 U.S. at 157.

67. Id. at 135-136.

68. Id. at 135.

69. ZELEZNY, supra note 34 , at 130-131. 
asserted, "[t]o me, differentiation between 'public figures' and 'public officials' and adoption of separate standards of proof for each have no basis in law, logic, or First Amendment policy. . .I therefore adhere to the New York Times standard in the case of 'public figures' as well as 'public officials."'70

Subsequent cases further expanded the scope of defamation actions. In Rosenbloom v. Metromedia (1971), ${ }^{71}$ the plurality opinion by Justice Brennan extended the New York Times' standard to include "any matter of legitimate public concern or general interest." ${ }^{72}$ Rosenbloom was arrested on charges of possession of obscene literature and news of the arrest was broadcast on the radio. ${ }^{73}$ After Rosenbloom was acquitted of the criminal obscenity charges he filed suit against Metromedia claiming that the radio broadcasts constituted libel per se. ${ }^{74}$ The district court held in favor of Metromedia, ${ }^{75}$ and the appellate court reversed. ${ }^{76}$ The Supreme Court upheld the appellate court decision. Justice Brennan announced the Court's decision and expressed that

the constitutional standard of knowing or reckless falsity applied whenever the allegedly defamatory statements related to the plaintiff's involvement in a matter of public or general concern, such as in the case at bar, regardless of whether the plaintiff was a "public official," a "public figure," or a "private individual."77

This analysis shifted focus from the status of the plaintiff to the content of speech. ${ }^{78}$

In Gertz v. Robert Welch, ${ }^{79}$ the Supreme Court once again reverted the emphasis back to the status of the plaintiff and held 5-4 that private figures need greater protection from defamation and consequently, do not need to prove the New York Times' actual malice standard. ${ }^{80}$ According to Justice Lewis Powell who wrote for the majority, "[t]he principal issue in this case is whether a newspaper or broadcaster that publishes defamatory falsehoods

70. Curtis Publ'g Co., 388 U.S. at 163-164.

71. 403 U.S. 29 (1971).

72. Nat Stern, Unresolved Antitheses of the Limited Public Figure Doctrine, 33 Hous. L. REV. 1027, 1034 (Winter 1996).

73. Rosenbloom v. Metromedia, Inc., 289 F. Supp. 737, 739 (E.D. Pa. 1968).

74. Id. at 744 .

75. Id. at 739 .

76. Rosenbloom v. Metromedia, Inc., 415 F.2d 892, 898 (3d Cir. Pa. 1969).

77. Rosenbloom, 403 U.S. at 30-31.

78. Craig, supra note 13, at 532 .

79. Gertz, 418 U.S. 323.

80. ZELEZNY, supra note 34, at 127 . 
about an individual who is neither a public official nor a public figure may claim a constitutional privilege against liability for the injury inflicted by those statements." ${ }^{\text {81 }}$ A private citizen involuntarily associated with a matter of general interest required a different rule than the New York Times actual malice standard. ${ }^{82}$ The court further held that states could define for themselves the appropriate standard of liability for publishing defamatory falsehoods about a private individual. ${ }^{83}$ While private individuals are not required to meet the actual malice standard, they still need to show the publisher was negligent in publishing a "damaging falsehood." 84

In a libel action, as the cases indicate, individuals are classified as private persons out of default when they are neither a public official nor any type of public figure. ${ }^{85}$ The Court also distinguished between all-purpose and vortex ${ }^{86}$ public figures in the Gertz decision:

A public figure within the meaning of the First Amendment rule requiring a public person to prove, as plaintiff in an action against communications media, defendant's knowledge or reckless disregard of falsity, is either an individual who achieves such pervasive fame or notoriety that he becomes a public figure for all purposes and in all contexts, or an individual who voluntarily injects himself or is drawn into a particular public controversy and thereby becomes a public figure for a limited range of issues; in either case such persons assume special prominence in the resolution of public questions. ${ }^{87}$

These distinctions have since been labeled "all-purpose" and "limited" public figures. ${ }^{88}$

The Court reasoned that public figures and officials bear a heavier burden of proof since they invite public exposure and comment, and voluntarily expose themselves to an increased likelihood of defamatory statements. Additionally, they have better means of self-defense to counteract false statements since they enjoy media attention and access. ${ }^{89}$ According to

81. Gertz, 418 U.S. at 331.

82. Id.

83. Id.

84. Craig, supra note 13 , at $532-533$.

85. ZELEZNY, supra note 34 , at 127.

86. The term "vortex" comes from the Curtis Publishing Co. case where the plaintiff was thrown into the "vortex" of a public controversy. Cutis Publ'g Co., 388 U.S. at 154-155.

87. Gertz, 418 U.S. at 329.

88. MidDLETON et al., supra note 24 , at 108 .

89. Id. at $108-109$ 
attorney Bruce W. Sanford, "[t]wo themes underlie Justice Powell's publicprivate distinction in Gertz: The greater availability of the self help remedy of rebuttal to public personas and the enhanced risk of scrutiny public persons necessarily assume." 90

As precedent indicates, courts have focused primarily on the status of the plaintiff in libel action suits, defining public officials, public figures, and clarifying all purpose and vortex public figures. The Supreme Court has also recognized that the subject matter - matters of public concern - rather than the status of the plaintiff, can trigger the actual malice standard. The Court has also given deference to the states to provide greater protection to private figures to prove something less than the New York Times' actual malice standard. ${ }^{91}$ However, the consideration as to whether college coaches are public officials or public figures, or whether college sports are a matter of public concern, is not always clear.

\section{COACHES: PRIVATE OR PUBLIC FIGURES}

The Gertz case leaves many questions unanswered: "What constitutes a public controversy? Must an individual desire publicity to be a public figure, or is engaging in an activity likely to invite publicity sufficient? How much media access must a public figure possess?"92 Additionally, the scope of the all-purpose category is not clearly defined in the Gertz opinion." 93 According to Corbelli, the case "allows public figure status to be conferred on a plaintiff solely on the basis of his or her notoriety."94

In Chuy v. The Philadelphia Eagles Football Club (1979), a columnist for the Philadelphia Bulletin incorrectly reported that Chuy, a professional football player, suffered from polycythemia vera, a blood clot condition. ${ }^{95}$ This story was picked up by AP and published in various newspapers across the country, including the $L A$ Times. ${ }^{96}$ Chuy panicked after reading the Times article, suffered a breakdown, could not cope with life and avoided people. ${ }^{97}$

90. Bruce W. Sanford, LiBel And Privacy The Prevention ANd Defense Of Litigation 237 (1985).

91. Gertz, 418 U.S. at 347.

92. Walker, supra note 38 , at 961.

93. James Corbelli, Comment, Fame and Notoriety in Defamation Litigation, 34 HASTING L.J. $809,816(1983)$.

94. Id. at 810.

95. 595 F.2d 1265, at 1269 (3rd Cir. 1979).

96. Id. at 1270 .

97. Id. 
He brought a suit against the Eagles and the NFL for antitrust violations, breach of contract, intentional infliction of emotional distress and defamation. ${ }^{98}$

Regarding defamation, the jury found that statements made by the Eagle's team physician tended to injure Chuy's reputation, but that the columnist who wrote the article did not understand that publication of these comments would injure Chuy's reputation. ${ }^{99}$ The court determined that a professional football player was a public figure because professional football is subject to constant media attention even though the plaintiff did not actively seek attention. ${ }^{100}$ It was noted that professional athletes, at least as to their playing careers, generally assume a position of public prominence. ${ }^{101}$ Likewise, it seems that coaches of professional sports teams would be considered public figures at least to their coaching careers. Professional sports command a significant amount of public attention and coaches, similar to athletes, receive media scrutiny whether they actively seek it or not.

In Warford, University of Pittsburgh assistant basketball coach Reggie Warford brought suit against the Lexington, Kentucky newspaper for a 1986 reprint of a story alleging that he offered high school basketball standout Steve Miller money to sign. ${ }^{102}$ While the trial court initially designated Warford a private person, the appellate court later reversed and regarded him as a public figure due to his recruiting efforts at a Big East Conference school. ${ }^{103}$ However, after implementing Gertz factors, ${ }^{104}$ the Kentucky Supreme Court termed Warford a private person at the time of the alleged defamation, reversing the lower court's decision. ${ }^{105}$ According to the Court, Warford did not accept the risk of defamation in the manner and precedence of Gertz and subsequent cases, and his recruiting efforts at a Division I NCAA school did

98. Id.

99. Id. at 1279.

100. Chuy, 595 F.2d at 1280.

101. Id.

102. Warford, 789 S.W.2d at 760 .

103. Id.

104. The Kentucky Supreme Court based its analysis to determine Warford's status as a public figure on factors defined by the Supreme Court in Gertz by asking

(1) in what particular and identifiable public controversy (2) did appellant by some voluntary act involve himself to the extent that he either assumed a role of public prominence, or was in a position to influence others or the outcome of the controversy, and (3) did appellant enjoy regular and continuing access to the media?

Id. at 766 .

105. Id. at 769 . 
not warrant public figure status. ${ }^{106}$ As far as media access, the Court considered him a private figure since he only enjoyed occasional access and his "post-defamation rebuttal" did not necessitate the frequent media access afforded public figures. ${ }^{107}$

As the Warford case illustrates, it is not always obvious whether a coach is a public or private figure. In determining whether a plaintiff is a limited purpose public figure, lower courts use the following four-step analysis:

(1) Isolate the controversy and determine the scope of the public's interest;

(2) Examine the plaintiff's role in the controversy;

(3) Determine if the defamatory statement is germane to the plaintiff's role in the controversy; and

(4) Analyze the extent of the plaintiff's access to channels of media communication. ${ }^{108}$

Case law and academic opinion seem to support the view that athletes and coaches are public figures whose lives are a matter of public concern. ${ }^{109}$ In general, sport is definitely in the public interest, coaches should have control over their programs, and coaches generally have access to channels of media communication. However, the plaintiff's role in the controversy allows for the state to determine the appropriate standard of liability, allowing a coach to be labeled a private person rather than a public figure. However, the court has the flexibility to classify a coach as a private person rather than a public figure when the coach's actions or role in the controversy would generally not warrant public attention. ${ }^{110}$

\section{MEDIA DEFENSES AGAINST LIBEL}

Obviously, truth would appear to be the best defense against libel, but the case law is not consistent as to whether the defendant has the burden of proving truth as a defense.

106. Id.

107. Id. at $764,771 \& 774$.

108. See, e.g., Waldbaum v. Fairchild Publ'ns, Inc., 627 F.2d 1287, 1297 (D.C. Cir. 1980), cert. denied, 449 U.S. 898 (1980); Trotter v. Jack Anderson Enters., 818 F. 2d 431, 434 ( $5^{\text {th }}$ Cir. 1987); Silvester v. Am. Broadcasting Cos., 839 F.2d 1491, 1494 (11 ${ }^{\text {th }}$ Cir. 1988). For cases based on slight variations of these criteria, see, Marcone v. Penthouse Int'l Ltd., 754 F.2d 1072, 1082 (3d Cir. 1985), cert denied, 474 U.S. 864 (1985); McDowell v. Paiewonsky, 769 F.2d 942 (3d Cir. 1985).

109. Craig, supra note 13, at 539; but see, Warford, 789 S.W.2d at 758.

110. Warford, 789 S.W.2d at 770 . 
Philadelphia Newspapers $v$. Hepps (1986) is a case involving a private businessman who franchised a chain of beer, soft drink, and snack stores; and the Philadelphia Inquirer, that published a series of articles stating that Hepps had ties to organized crime. ${ }^{111}$ The Supreme Court held that a private figure seeking damages in a defamation action against a newspaper must bear the burden of proving that defamatory statements of public concern are false. ${ }^{112}$ The Supreme Court rationalized that this was necessary in order to avoid a chilling effect on the First Amendment's protection of true speech, therefore, a private figure plaintiff must bear the burden of showing that the speech at issue was false before recovering damages for defamation from a media defendant. The state courts that have considered this issue since Gertz have reached differing conclusions. ${ }^{113}$

Whether or not the defendant has the burden of proving truth, the press can win a libel case by providing evidence that they were responsible in their reporting methods even if they do not report the truth. Associated Press $v$. Walker (1967), ${ }^{114}$ a companion case to Curtis Publishing Co. v. Butts, involved an incorrect Associated Press news dispatch about Major General Edwin Walker, who was also considered a public figure. In this case, the Associated Press received information from a correspondent at the events who had a reputation for competence. ${ }^{115}$ The Supreme Court also noted that nothing in the series of events leading to the publication departed from accepted publishing standards. ${ }^{116}$ The case was reversed and remanded to the Texas Court of Civil Appeals. ${ }^{117}$

Opinion privilege is also a defense, but not an absolute one. Opinion is privileged when it is "fairly made by a person in the discharge of some public and private duty, whether legal or moral, or in the conduct of one's own affairs

111. 475 U.S. $767,768-769$ (1986).

112. Id.

113. Compare, e.g., Denny v. Mertz, 106 Wis. 2d 636, 654-658 (Wis. 1982), cert. denied, 459 U.S. 883 (1982), and Memphis Publishing Co. v. Nichols, 569 S.W. $2 d 412$ (Tenn. 1978) (cases showing that defendant must bear burden of showing truth), with Gazette, Inc. v. Harris, 229 Va.1, 15-16 (Va. 1985), cert. denied, Fleming v. Moore, 473 U.S. 905 (1985) and Madison v. Yunker, 180 Mont. 54, 67 (1978) (cases showing that plaintiff must bear burden of showing falsity). .

114. Associated Press v. Walker, 389 U.S. 28 (1967).

115. Curtis Publishing Co., 388 U.S. at 158.

116. Id. at 159.

117. Associated Press, 389 U.S. 28. 
in matters where his interest is concerned."118 Immunity is conditioned on the defendant's good behavior; that the defendant acted properly. ${ }^{119}$

In Milkovich v. Lorain Journal Co. (1990), ${ }^{120}$ a high school wrestling coach and school superintendent filed lawsuits against the Lorain Journal saying they were "falsely accused of perjury in a newspaper column."121 The trial court granted summary judgment for the newspaper and the appellate court affirmed holding that the article was an opinion protected by the First Amendment. ${ }^{122}$ The United States Supreme Court reversed, holding that the First Amendment did not prohibit application of Ohio's libel laws to the alleged defamation. ${ }^{123}$

The Court found that there was no absolute privilege protecting opinion from application of defamation laws and that the dispositive question was whether a reasonable fact finder could conclude that respondents' statements implied that petitioner perjured himself. ${ }^{124}$ The connotation that the coach perjured himself was sufficiently factual to be susceptible of being proved true or false. ${ }^{125}$ The Supreme Court also indicated that the plaintiff had the burden of proving that the connotations were false and made with some level of fault. ${ }^{126}$ The Court refused to create a separate constitutional privilege for opinions or "otherwise factual-sounding statements that appear in opinion contexts." 127

\section{RECOMMENDATIONS FOR COACHES}

For coaches, certain preventative measures can be taken to improve their relationship with the media and avert defamatory action. First and foremost, they should maintain a professional relationship with the media and make themselves accessible to sports journalists after games, during press conferences, and other official gatherings. After all, coaches and the media share a symbiotic relationship. Coaches rely on the media for public exposure

118. Ray Yasser, James R. MCCuRdy, C. Peter Goplerdd, \& Maureen ARellano WESTON, SPORTS LAW: CASES AND MATERIALS $769-770\left(4^{\mathrm{TH}}\right.$ ed. 2000$)$.

119. Id. at 770 .

120. 497 U.S. 1 (1990).

121. Craig, supra note 13 , at 535 .

122. Milkovich, 497 U.S. 1.

123. Id at 20.

124. Id.

125. Id at 21 .

126. Id. at 20.

127. ZELEZNY, supra note 34, at 116. 
for their team and themselves, and the media needs coaches' quotes and commentary to add legitimacy to their stories. It is a mutually beneficial relationship, which both sides need to recognize.

Coaches also should understand the importance of maintaining a positive public image, which is in part influenced by media coverage. At the Coach's Communication Resource Site, the following suggestions are made for maintaining beneficial media relations:

- Understand the media-they aren't your enemies; they are just doing their job. But you can maintain control of the interview by understanding the angle of the story.

- Promote your own agenda - -don't repeat negatives and stick to your main message.

- Don't be baited-even if a reporter fires questions at you quickly, take your time, maintain your focus, and control the pace... Keep your thoughts clear and concise to avoid being misquoted. ${ }^{128}$

Regarding daily activities, coaches should be discreet in their actions and should clearly adhere to all NCAA rules and regulations. ${ }^{129}$ In interviews, they should use clear, concise language and avoid any ambiguous words that could be misconstrued either by reporters or the public. The Coach's Communication Resource Site urges coaches not to answer "what if" questions, suggests that they "correct misstatements," and not to view anything as "off the record." 130

Finally, coaches should know the law and/or hire a good attorney. In this way, they will know what, if any, claims may be brought, and the category of plaintiff and proof of fault required for potential legal action associated with their situation. If they pursue a lawsuit, they need to understand both sides' responsibilities and how to specifically maximize their burdens of proof.

\section{REPORTERS: ETHICS AND RECOMMENDATIONS}

While it is difficult to understand what 'freedom of the press' means today, ${ }^{131}$ the media especially needs to adhere to journalistic standards and

128. COACH'S COMMUNICATION RESOURCE SITE, MEDIA RELATIONS: MEDIA RELATIONS TIPS (last visited September 9, 2002), at http://sportsmediachallenge.com/playbook/media/mrtips.htm.

129. Warford, 789 S.W. 2 d 758.

130. COACH'S COMMUNICATION RESOURCE SITE, supra note 128.

131. Cynthia Carter \& Stuart Allen, 'If it Bleeds, it Leads': Ethical Questions about Popular Journalism, in ETHICS AND MEDIA CULTURE: PRACTICES AND REPRESENTATIONS 140 (David Berry, ed., 2000). 
ethics. They not only represent public interest, but also provide readers and viewers with accurate and objective information intended to propel debate and the free-flow of ideas.

Reporter Carl Bernstein criticized the modern media by saying:

Increasingly the America rendered today in the American media is illusionary and delusionary-disfigured, unreal, disconnected from the true context of our lives. In covering actually existing American life, the media - weekly, daily, hourly-break new ground in getting it wrong. The coverage is distorted by celebrity and the worship of celebrity; by the reduction of news to gossip, which is the lowest form of news; by sensationalism, which is always a turning away from a society's real condition; and by a political and social discourse that we - the press, the media, the politicians, and the people-are turning into a sewer. ${ }^{132}$

While this may seem overly cynical, reporters need to contemplate their stories' implications and take responsibility for their actions. David Pritchard presents the following definition for media accountability, "The process by which media organizations may be expected or obliged to render an account of their activities to their constituents." 133

While the Pew Research Center for The People \& The Press reported that large majorities of media practitioners believe the "line between reporting and commentary has blurred" with half admitting a "trend toward sensationalism," 134 Washington Post reporter Howard Kurtz believes things have improved. As host of CNN's "Reliable Sources," he said, "[m]y sense is that there's probably less public appetite for some of the frivolous gossip and interviews with airhead celebrities that we have thrived on for so long. It would be impossible for the news business not to be changed by the events of September 11, and I hope that change is for the better."135

As a general guideline, the media need to understand and practice sound journalistic practice and ethics. ${ }^{136}$ By using reliable sources and checking sources and the content of a story for accuracy and neutrality, reporters can

132. Id. at 133 .

133. David Pritchard, Introduction: The Process of Media Accountability, in CITIZENS, ETHICS, AND THE LAW: Holding The Media AcCountable 2 (David Pritchard ed., 2000 ).

134. STRIKING THE BALANCE, supra note 4.

135. Howard Kurtz, The Line between Journalism and Sensationalism (Sept. 26, 2001), at http://www.cnn.com/2001/COMMUNITY/09/26/kurtz/.

136. Curtis Publ'g Co., 388 U.S. at 163-164. 
avoid mistakes. ${ }^{137}$ Reporters should always cover both sides of an issue and maintain professionalism with sources. If a coach says "off the record," it is much more important long-term to gain his or her trust than to use a good quote. After all, coaches can engage in 'freezeouts' where they refuse to talk to a certain reporter individually. Journalists should respond to informal complaints swiftly and courteously and handle them in an efficacious manner. And finally, after publication if there is indeed a mistake, the media should print retractions promptly and effectively. ${ }^{138}$

\section{CONCLUSION}

While the relationship between college coaches and the media that cover them appears to be a game of tug-of-war, through mutual respect and understanding, it can instead resemble a dance. ${ }^{139}$ After all, both sides should realize the complementary elements and the give and take required to promote fans' understanding of sport and the actors who participate.

\section{ABOUT THE AUTHORS}

PAMEla LAuCELla is a Ph.D. student in the School of Journalism and Mass Communication at the University of North Carolina at Chapel Hill. She studies historical and contemporary issues in sport, specifically those dealing with race and gender. Before coming to UNC, she obtained a Master of Arts from George Washington University and a Bachelor of Arts from the University of Virginia. Pamela also has work experience in sports marketing, sports reporting, and aviation.

Barbara OsborNe, J.D. is currently an Assistant Professor and Graduate Coordinator for the Sport Administration specialization in the department of Exercise and Sport Science at the University of North Carolina at Chapel Hill. Prior to her appointment at UNC, she worked for 14 years as an athletics administrator in intercollegiate athletics. A lawyer and member of the Massachusetts Bar Association, Barbara has also had experience as a coach, public relations coordinator, television sports commentator, publisher and sports information director. Her most recent publications include articles on

137. Id.

138. ZELEZNY, supra note 34.

139. HeRbERt Gans, Deciding What's News: A Study OF CbS Evening News, NbC NIGHTLY NEWS, NEWSWEEK \& TIME 116 (1979). Gans talked about the journalist/source relationship as being a dance since they both pursue each other for access. 
liability and head injury and pay equity for female coaches and athletics administrators in college sport.

\section{REFERENCES}

American Law Institute (1977). Restatement of the law of torts (2nd). St. Paul, MN: American Law Institute Publishers.

Associated Press v. Walker, 389 U.S. 28 (1967).

Baker, M.R. (2000, April). Full court press. Brills Content, pg. 100.

Carey, J. (200, July/August). At their feet, or at their throat. Columbia Journalism Review, pg. 56.

Carter, C. \& Allen, S. (2000). 'If it bleeds, it leads': Ethical questions about popular journalism. In D. Berry (Ed.), Ethics and media culture: Practices and representations (pp. 132-153). Oxford: Focal Press.

Chuy v. The Philadelphia Eagles Football Club, 595 F.2d 1265 (3rd Cir. 1979).

Coach's Communication Resource Site, Media Relations: Media Relations Tips Retrieved September 9, 2002, from http://sportsmediachallenge.com/ playbook/media/mrtips.htm.

Corbelli, J. (1983). Comment: Fame and notoriety in defamation litigation. Hastings Law Journal, 34(2), 809-838.

Craig, A.K. (1994). The rise in press criticism of the athlete and the future of libel litigation involving athletes and the press. Seton Hall Journal of Sports Law, 4(2), 527-552.

Curtis Publ'g Co. v. Butts, 388 U.S. 130 (1967).

Denny v. Mertz, 106 Wis. 2d 636 (Wis. 1982), cert. denied, 459 U.S. 883 (1982).

Gans, H. (1979). Deciding what's news: A study of CBS Evening News, NBC Nightly News, Newsweek \& Time. New York: Pantheon Books.

Gazette, Inc. v. Harris, 229 Va. 1 (Va. 1985), cert. denied, Fleming v. Moore, 473 U.S. 905 (1985).

Gertz v. Robert Welch, Inc., 418 U.S. 323 (1974).

Gifis, S.H. (1991). Barron's law dictionary ( $3^{\text {rd }}$ ed.). New York: Barron's Educational Series, Inc.

Goodchild, S. (1986). Note: Media counteractions: Restoring the balance to modern libel law. Georgetown Law Journal, 75(1), 315-359. 
Kirby, J. (1986). Fumble: Bear Bryant, Wally Butts, and the great college football scandal. New York: Dell Books.

Kurtz, H. (2001, September 26). The line between journalism and sensationalism. Retrieved on September 4, 2002, from http://www.cnn.com/2001/COMMUNITY/09/26/kurtz/.

Madison v. Yunker, 180 Mont. 54 (Mt. 1978).

Marcone v. Penthouse Int'l Ltd., 754 F.2d 1072 (3d Cir. 1985), cert. denied, 474 U.S. 864 (1985).

McCleneghan, J.S. (1994, March 19). Sports columnists sound off. Editor \& Publisher, pg. 72.

McDowell v. Paiewonsky, 769 F.2d 942 (3d Cir. 1985).

Memphis Publishing Co. v. Nichols, 569 S.W.2d 412 (Tenn. 1978).

Middleton, K.R., Trager, R., \& Chamberlin, B.F. (2000). The law of public communication (5th ed.). New York: Longman Publishers.

Milkovich v. Lorain Journal Co. et al., 497 U.S. 1 (1990).

New York Times v. Sullivan, 273 Ala. 656 (Ala. 1962), rev'd, 376 U.S. 254 (1964).

The Pew Research Center for the People \& the Press (1999, March 30). Striking The Balance: Audience Interests, Business Pressures and Journalists' Values. Retrieved September 4, 2002, from http://208.240.91.18/press99sec3.htm.

Philadelphia Newspapers, Inc., et al., v. Hepps et al., 475 U.S. 767 (1986).

Pritchard, D. (2000). Introduction: The process of media accountability. In D. Pritchard (ed.), Citizens, ethics, and the law: holding the media accountable. (pp. 1-10). Bloomington, IN: Indiana University Press.

Rosenbloom v. Metromedia, Inc., 289 F.Supp. 737 (E.D. Pa. 1968), rev'd, 415 F.2d 892 (3d Cir. 1969), affd, 403 U.S. 29 (1971).

Rushin, S. (2000, January 10). Rush from judgment. Sports Illustrated, p. 24.

Sanford, B.W. (1985). Libel and privacy the prevention and defense of litigation. New York: Law \& Business, Inc./Harcourt Brace Jovanovich, Publishers 1985).

Silvester v. Am. Broadcasting Cos., 839 F.2d 1491 (11 ${ }^{\text {th }}$ Cir. 1988).

Stern, N. (1996, Winter). Unresolved antitheses of the limited public figure doctrine. Houston. Law Review, 33(4), 1027-1102. 
Taylor, P. (2001, November 19). UCLA: A secret the deep, talented Bruins can't keep: They're of championship caliber. Sports Illustrated, p. 104.

Telander, R. (1984). The written word: Player-press relationships in American sports. Sociology of Sport Journal, 1(1), 3-14.

Trotter v. Jack Anderson Enters., 818 F.2d 431 ( $5^{\text {th }}$ Cir. 1987).

Waldbaum v. Fairchild Publ'ns, Inc., 627 F. 2d 1287 (D.C. Cir. 1980), cert. denied, 449 U.S. 898 (1980).

Walker, E. (1993). Comment: Defamation law: Public figures - who are they? Baylor Law Review, 45(4), 955 - 983.

Warford v. Lexington Herald-Leader Co., 789 S.W.2d 758 (Ky. Sup. Ct. 1990).

Wong, G.M. (1994). Essentials of amateur sports law (2nd ed.). Westport, CT: Greenwood Publishing Group, Inc.

Yasser, R., McCurdy, J.R., Goplerud, C.P. \& Weston, M.A. (2000). Sports law: Cases and materials (4th ed.). Cincinnati, $\mathrm{OH}$ : Anderson Publishing Co.

Zelezny, J.D. (2001). Communications law: Liberties, restraints, and the modern media (3rd ed.). Belmont, CA: Wadsworth Publishing. 